\title{
Impacts of Off-Road Vehicles (ORVs) on Macrobenthic Assemblages on Sandy Beaches
}

\author{
Thomas A. Schlacher · Darren Richardson • \\ Ian McLean
}

Published online: 12 February 2008

(c) Springer Science+Business Media, LLC 2008

\begin{abstract}
Sandy beaches are the prime sites for human recreation and underpin many coastal economies and developments. In many coastal areas worldwide, beach recreation relies on the use of off-road vehicles (ORVs) driven on the shore. Yet, the use of ORVs is not universally embraced due to social conflicts with other beach user groups and putative environmental consequences of vehicle traffic on sandy shores. Such ecological impacts of ORVs are, however, poorly understood for endobenthic invertebrates of the intertidal zone seawards of the dunes. Consequently, this study quantified the degree to which assemblages of intertidal beach invertebrates are affected by traffic. The study design comprised a series of temporally replicated spatial contrasts between two reference sites (no ORVs) and two beaches with heavy ORV traffic (in excess of 250,000 vehicles per year) located in SouthEast Queensland, Australia. Macrobenthic assemblages on ORV-impacted beaches had significantly fewer species at substantially reduced densities, resulting in marked shifts in community composition and structure. These shifts were particularly strong on the middle and upper shore where vehicle traffic was concentrated. Strong effects of ORVs were detectable in all seasons, but increased towards the summer months as a result of heavier traffic volumes. This study provides clear evidence that ORVs can have substantial impacts on sandy beach invertebrates that are manifested throughout the whole community.
\end{abstract}

T. A. Schlacher $(\varangle) \cdot$ I. McLean

Faculty of Science, Health, and Education, University of the Sunshine Coast, Maroochydore QLD-4558, Australia e-mail: tschlach@usc.edu.au

D. Richardson

BMT WBM, 490 Upper Edward Street, Q-4000 Brisbane, Australia
Demonstrating such an ecological impact caused by a single type of human use poses a formidable challenge to management, which needs to develop multi-faceted approaches to balance environmental, social, cultural, and economic arguments in the use of sandy shores, including management of "beach traffic."

Keywords Sandy beaches - Macrobenthos . Human impacts · Coastal management · Off-road vehicles . Conservation

\section{Introduction}

Sandy beaches dominate the world's ocean shores, comprising two-thirds of all ice-free coastlines (Bascom 1980). Most of the global human population is concentrated in the coastal fringe, and sandy beaches are the most intensively used type of shore worldwide (Gormsen 1997; Klein and others 2004). Sharply rising population densities in the coastal zone, coupled with much improved personal economic resources and availability of leisure time, place escalating pressures on sandy beaches (Schlacher and others 2006). Most prominently, large tracts of coastal habitat have been lost to residential building and associated infrastructure developments, and the dunes backing sandy beaches have become severely compressed or destroyed (Nordstrom 2000). The ecological impacts of direct human pressures on beaches are varied, ranging from severe disruption of sand transport and erosion to chemical pollution and litter (Brown and McLachlan 2002; Schlacher and others 2006).

Recreational activities are one of the most prominent forms of direct human uses of sandy beaches, and include walking, swimming, surfing, beach camping, bait and 
shellfish collecting, and fishing (Priskin 2003a; Buckley 2004; Klein and others 2004; Davenport and Davenport 2006). In many parts of Australia and elsewhere, leisure activities involve the use of off-road vehicles (ORVs) driven on the beaches (Steiner and Leatherman 1981; Stephenson 1999; Priskin 2003a; Moss and McPhee 2006; Schlacher and Thompson 2007; Schlacher and others 2007a). ORVs can, however, be environmentally highly destructive (Palmer and Leatherman 1979; Godfrey and Godfrey 1980). Negative environmental effects of ORV traffic in the dune-beach system include severe sediment disruption and erosion (Anders and Leatherman 1987; Priskin 2003b; Schlacher and Thompson in press), destruction of dune vegetation (Luckenbach and Bury 1983; Rickard and others 1994), and disturbance of threatened vertebrates such as birds and turtles, resulting in lower reproductive success and population declines (Hosier and others 1981; Buick and Paton 1989; Watson and others 1996; Williams and others 2004).

Macrobenthic invertebrates (e.g., worms, clams, crustaceans, etc.) play a key role in the trophic architecture of sandy beaches, supporting higher-order consumers such as shorebirds and fishes (Heymans and McLachlan 1996; McLachlan and Brown 2006; Peterson and others 2006), and contribute to nutrient recycling on beaches (Soares and others 1997). These largely infaunal species generally occupy the sand matrix of the intertidal zone where most of the vehicle traffic is concentrated (Schlacher and Thompson 2007), and are thus potentially vulnerable to impacts by ORVs via direct crushing of individuals (Wolcott and Wolcott 1984; van der Merwe and van der Merwe 1991; Blankensteyn 2006; Moss and McPhee 2006; Schlacher and others 2007a). Yet, despite their ecological importance, the effects of ORV traffic on macrobenthic assemblages are poorly understood and community-wide effects are not known. Published information on ORV impacts generally relate to single species only (e.g., Moss and McPhee 2006), or small sub-sets of the assemblages (van der Merwe and van der Merwe 1991). Also, existing data on impacts originate from short-term field experiments or from temporally limited surveys of species population sizes, lowering the robustness of predictions about the generality and consistency of putative ORV impacts over time.

Escalating human pressures on sandy beaches in the form of recreational ORV traffic require the development of management responses based on scientifically robust and defensible evidence of ecological impacts (James 2000; Micallef and Williams 2002; Schlacher and others 2006; Schlacher and others 2007b). This evidence is currently not available for whole macrobenthic assemblages - a key ecological component of sandy beaches that is potentially vulnerable to vehicle traffic. Thus, the chief objective of this study was to determine whether ORV traffic on sandy beaches causes changes to communities of invertebrates subjected to vehicle traffic. Specifically, it aimed to (a) quantify the response of entire faunal communities to ORV traffic, in terms of changes in community structure, diversity, and abundance, and (b) assess whether ecological impacts by ORVs are consistent over time compared with natural variability in community attributes.

\section{Materials and Methods}

\section{Beaches Studied}

Macrobenthic assemblages were compared between two beaches subjected to heavy ORV traffic ("impact beaches") and two beaches without vehicle traffic ("reference beaches;" Fig. 1). All four beaches are located in SouthEast Queensland, on the Eastern seaboard of Australia. The two reference beaches, Peregian- and Sunrise Beach, are situated to the south of the town of Noosa, and are subjected only to pedestrian use (human trampling). They have no appreciable traffic by off-road vehicles (ORVs), save for the occasional search and rescue vehicle (Fig. 1). By contrast, the two beaches north of Noosa, Teewah Beach and Noosa North Shore, receive high volumes of ORV traffic all year. More than a quarter million $(265,241)$ vehicles traverse the beach per year (Noosa Council personal communication, 1 June 2006); this translates to an average of 727 vehicles crossing the beach per day. However, during peak holiday periods and public holidays, daily traffic volumes can exceed 5000 vehicles in a single day (Richardson and others 2006).

The vast majority of this beach traffic is by recreational ORVs, which comprise $91 \%$ of all beach traffic, followed by residents and tradesman who make up $7 \%$ of beach traffic. All other user types (e.g., motor bikes, commercial fishermen, tour buses, etc.) comprise only a minor $(<1 \%)$ fraction of the beach traffic. Overall, $93 \%$ of all beach traffic is for recreational purposes, $2.3 \%$ for commercial reasons, and $5.2 \%$ by local residents. Thus, almost all people travelling in vehicles on the beaches do so for leisure activities (Richardson and others 2006).

Beach traffic volumes are lower during the austral winter (i.e., May to August) at 16,000-18,000 vehicles per month, but double to over 30,000 vehicles per month during the peak summer season in December and January. Recreational users mostly drive the strong seasonality in beach traffic, whereas commercial traffic is relatively stable at around 1500-2000 vehicles per month (Richardson and others 2006).

All beaches were sampled on three occasions, corresponding broadly to low traffic volumes during the austral winter (30 July-6 August, 2005), moderate traffic 
Fig. 1 Location of the study area in Southern Queensland, Australia (a), and (b) the area surveyed for macrobenthic assemblages at two beaches subjected to off-road vehicle (ORV) traffic (Teewah Beach and North Shore) contrasted with two reference sites (Sunrise and Peregian Beach) without vehicular beach traffic
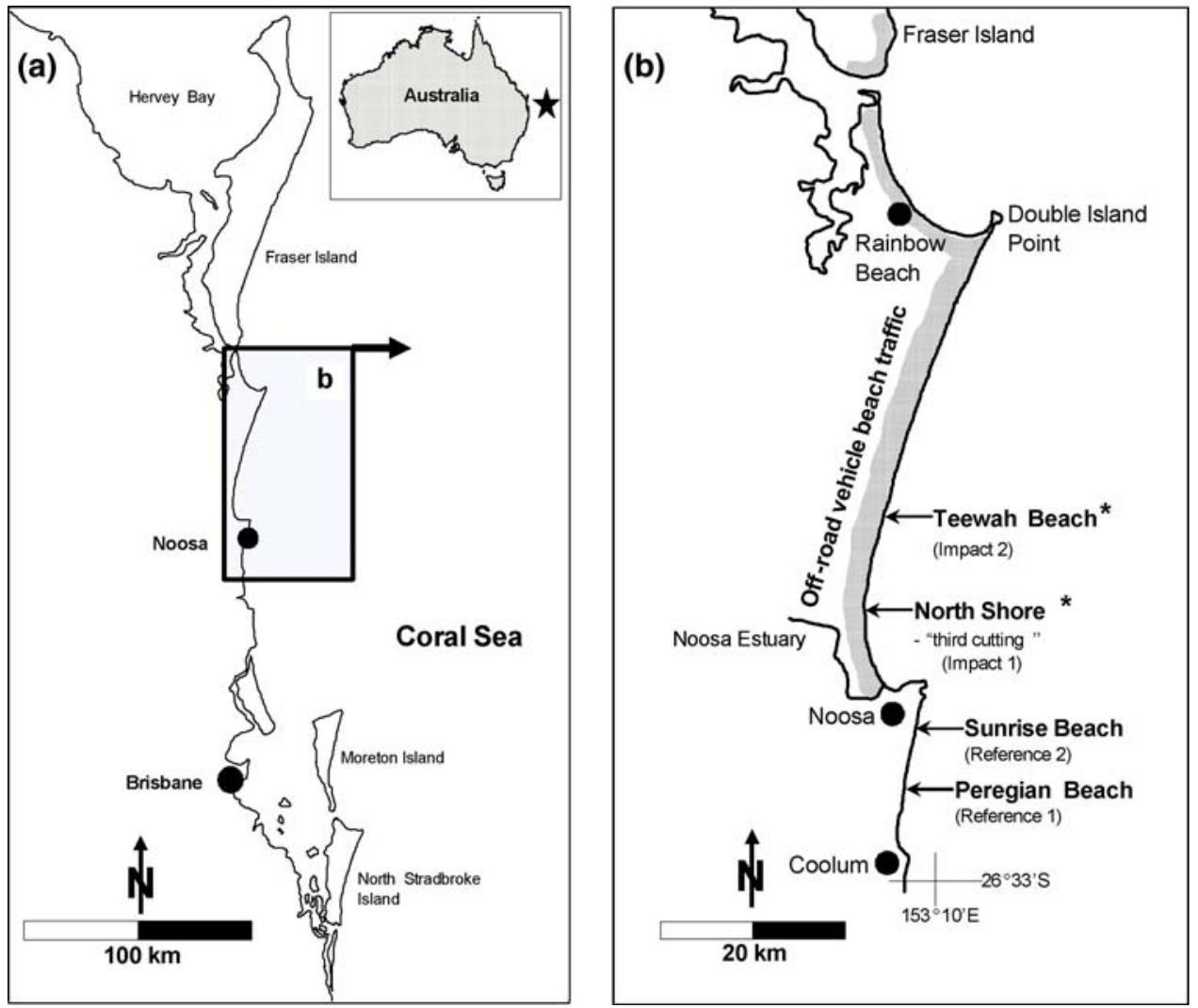

(13-18 December, 2005, one week before the peak Christmas period) and from 11-16 January 2006 after the peak traffic period of the Christmas/New Year summer holidays in Australia.

\section{Traffic Surveys}

Vehicle surveys were conducted on both beaches that received ORV traffic during each season when the fauna was sampled. The chief purpose of the vehicle surveys was to determine the spatial distribution of traffic across the beach face (i.e., from the dunes to swash zone). To this end, the beach was divided into $10-\mathrm{m}$ wide bands that ran for $100 \mathrm{~m}$ parallel to the shoreline. The most landward band was located at the base of the foredunes and the most seaward band was located in the swash zone below the effluent line.

The boundaries of these "vehicle count bands" were marked with small pieces of flagging tape inserted into the sand. These boundary markers were small enough not to be noticed by drivers (avoiding possible bias), but easily visible to observers. Observers, who either posed as tourists or sunbathers at the foredune, recorded the position and time of each passing vehicle. Both the markers and observers were inconspicuous enough not to bias driver behavior.
Traffic was recorded from the time of predicted high tide until the next low tide.

Fauna Sampling

At each beach, the macrobenthos was sampled across five transects (spaced $30 \mathrm{~m}$ apart along the shore) on each occasion. Transects extended from the base of the foredunes to the low water spring tide (LWST). Twelve levels (stations) were sampled on each individual transect, progressing at mid-tide from level 12 (near the base of the foredune) to level 1 located in the swash zone at the time of predicted low water. Thus, spatial sampling coverage was 180 samples per beach over the study period $(3$ times $\times 5$ transects $\times 12$ levels per transect).

At each level, five cores (inner diameter $154 \mathrm{~mm}$, $200 \mathrm{~mm}$ deep) were taken and pooled into a composite sample. The fauna was then washed from the sediment in the swash through a $1 \mathrm{~mm}$ mesh sieve, and preserved in $80 \%$ ethanol. All macrofauna was identified to the lowest possible taxon, usually distinct species or operational taxonomic units (OTUs).

All faunal sampling was done two days before and after spring tides. A total of 720 samples was obtained $(3$ times $\times 4$ beaches $\times 5$ transects per beach $\times 12$ levels 
per transect), yielding 12,139 specimens; this comprehensive sampling coverage equates to $111 \mathrm{~m}^{3}$ of sand that was processed manually.

Triplicate sediment cores $(30 \mathrm{~mm}$ diameter, $100 \mathrm{~mm}$ deep) were excavated at each level and matched the position where faunal samples were taken. Triplicate cores were pooled for each level in the field and sealed in airtight plastic bags. In the laboratory, sand moisture content was measured as weight loss after drying to constant weight $\left(65^{\circ} \mathrm{C}\right.$ for 48 hours). Granulometry was determined by dry sieving through a nested series of sieves with mesh sizes of $4000 \mu \mathrm{m}, 2000 \mu \mathrm{m}, 1000 \mu \mathrm{m}, 500 \mu \mathrm{m}, 250 \mu \mathrm{m}, 125 \mu \mathrm{m}$, and $63 \mu \mathrm{m}$. Sediment statistics (e.g., mean grain size, sorting, skewness, kurtosis, etc.) were calculated with the GRADISTAT software, using the Folk and Ward method (Blott and Pye 2001).

\section{Data Analysis}

Zones across the beach face (i.e., lower, middle, and upper shore) were identified from similarities in environmental attributes across all beach levels sampled, using groupaverage clustering based on normalized Euclidean distance (Clarke and Warwick 2001). Five environmental variables were included in these cluster analyses: (1) percent sand moisture content, (2) elevation above low water (m), (3) station slope, (4) mean sediment grain size $(\varnothing)$, and (5) the position of each sample relative to the effluent line (binary).

A four factor (nested) analysis of variance (ANOVA) was used to test for differences in faunal density, species richness, and diversity (Shannon Wiener Index) at multiple spatial scales over time. Because unequal numbers of samples were collected from each zone (i.e., lower, middle and upper shore), samples were selected at random and eliminated from the data-set to balance the sample design. A total of 360 samples were included in the ANOVA test (i.e., 10 samples per zone per beach for each sampling occasion). The sources of variation included in the analyses were: (1) ORV versus controls (random, orthogonal), (2) Site (nested within ORV vs. Control), (3) Zone (fixed, orthogonal), and (4) Time (random, orthogonal). Cochran's $C$-Tests were used to test for homogeneity of variances. Untransformed data were used if transformations failed to stabilize heterogeneous variances, but the level of significance, $\alpha$, was then reduced from 0.05 to 0.01 to reduce the chance of making a Type I error (Underwood 1981, 1997). Pooling procedures, involving elimination of terms from the mean square estimates, were done if a term was nonsignificant at $p>0.25$ (Underwood 1981, 1997).

Multivariate differences in community structure between impact and reference beaches were tested with
Analyses of Similarity, ANOSIM (Clarke 1993, 1999). All tests were based on the Bray-Curtis resemblance function. As a diagnostic check for the possible effects of data transformations on the ANOSIM tests, contrasts were run separately for raw data $\left(\mathrm{x}^{\prime}=\mathrm{x}\right)$ and four transformations $\left(\mathrm{x}^{\prime}=\mathrm{x}^{0.25}, \mathrm{x}^{\prime}=\mathrm{x}^{0.5}, \quad \mathrm{x}^{\prime}=\log _{10} \mathrm{x}, \quad\right.$ and $\mathrm{x}^{\prime}=$ pres/abs $)$. This was done for each zone (i.e., upper, middle and lower beach) and season separately. The ANOSIM tests were complemented by nonmetric multidimensional scaling (NMDS) ordinations, to aid in visual identification of shifts in community structure between treatments. The contributions of individual taxa to total dissimilarities in community structure between reference and impact sites were identified with SIMPER (SIMilarity PERcentages) analyses (Clarke and Warwick 2001). The link between environmental variables and faunal community structure was tested with the BIO-ENV method (Clarke and Ainsworth 1993). Finally, differences in multivariate community variability over time between treatments were quantified as relative dispersion values according to Warwick \& Clarke (1993).

\section{Results}

\section{Habitat Characteristics}

All beaches were of the intermediate morphodynamic type and wave-dominated (Table 1). The beaches are moderately wide at 57-75 m, with an intermediate slope of 2.1$2.6^{\circ}$, and sediments consist of fine to medium sand, ranging in size from 272 to $371 \mu \mathrm{m}$ (Table 1). Waves along this coast are usually in the range of $0.5-2.5 \mathrm{~m}$, with a period of 7-20 s (Table 1), and the beaches are microtidal with maximum tide ranges $<2.5 \mathrm{~m}$.

There were no marked differences in sediment properties or beach morphology between ORV-impacted and reference beaches (Tables 1 and 2, Figs. 2-4). All beaches had highly similar sediment properties, slope, and sand moisture (Fig. 2a; ANOSIM: $r=0.081, p=0.22$ ) and their morphology, as measured by several compound indices, was not significantly different (Fig. 2b; ANOSIM: $r=0.23, p=0.51)$. No single compound index differed significantly between ORV-impacted and reference beaches (Deans Parameter: $\mathrm{t}_{(10)}=0.77, p=0.46$; Beach Index: $\mathrm{t}_{(10)}=1.88, \quad p=0.09 ; \quad$ Beach State Index: $\mathrm{t}_{(10)}=0.74, p=0.47$; Beach Deposit Index: $\mathrm{t}_{(10)}=0.06$, $p=0.06$ ). Beach profiles were highly similar between reference and impact beaches (Fig. 3), and remained stable over the study period. Finally, sediment became finer toward the upper beach, but there was no separate effect of treatment (i.e., ORV versus reference) on variations in sediment grain size (Table 2, Fig. 4). 
Table 1 Physical and morphodynamic characteristics of the beaches sampled

\begin{tabular}{|c|c|c|c|c|}
\hline & \multicolumn{2}{|l|}{ Reference beaches } & \multicolumn{2}{|l|}{ ORV-impacted beaches } \\
\hline & Peregian & Sunrise & Teewah & North Shore \\
\hline Latitude & $26^{\circ} 28^{\prime} 04^{\prime \prime} \mathrm{S}$ & $26^{\circ} 25^{\prime} 08^{\prime \prime} \mathrm{S}$ & $26^{\circ} 16^{\prime} 16^{\prime \prime} \mathrm{S}$ & $26^{\circ} 20^{\prime} 18^{\prime \prime} \mathrm{S}$ \\
\hline Longitude & $\begin{array}{l}153^{\circ} 05^{\prime} 58^{\prime \prime} \mathrm{E} \\
-95 \% \mathrm{CI}-+95 \% \mathrm{CI}\end{array}$ & $\begin{array}{l}153^{\circ} 06^{\prime} 36^{\prime \prime} \mathrm{E} \\
-95 \% \mathrm{CI}-+95 \% \mathrm{CI}\end{array}$ & $\begin{array}{l}153^{\circ} 04^{\prime} 01^{\prime \prime} \mathrm{E} \\
-95 \% \mathrm{CI}-+95 \% \mathrm{CI}\end{array}$ & $\begin{array}{l}153^{\circ} 03^{\prime} 42^{\prime \prime} \mathrm{E} \\
-95 \% \mathrm{CI}-+95 \% \mathrm{CI}\end{array}$ \\
\hline Beach width (m) & $57-68$ & $60-65$ & $71-75$ & $69-74$ \\
\hline Slope $\left({ }^{\circ}\right)$ & $2.1-2.3$ & $2.4-2.6$ & $2.2-2.4$ & $2.2-2.3$ \\
\hline \multirow[t]{2}{*}{ Mean grain size $(\mu \mathrm{m})$} & $272-334$ & $340-371$ & $274-300$ & 291-309 \\
\hline & $\min .-\max$ & $\min .-\max$ & $\min .-\max$ & $\min .-\max$ \\
\hline Wave height (m) & $0.8-1.8$ & $0.8-1.5$ & $0.5-1.5$ & $0.8-1.8$ \\
\hline \multirow[t]{2}{*}{ Wave period (s) } & $12.0-20.0$ & $10.6-13.8$ & $7.51-18.0$ & $10.5-13.8$ \\
\hline & $-95 \% \mathrm{CI}-+95 \% \mathrm{CI}$ & $-95 \% \mathrm{CI}-+95 \% \mathrm{CI}$ & $-95 \% \mathrm{CI}-+95 \% \mathrm{CI}$ & $-95 \% \mathrm{CI}-+95 \% \mathrm{CI}$ \\
\hline$\Omega$ - Deans parameter ${ }^{\mathrm{a}}$ & $1.6-2.3$ & $1.6-2.3$ & $2.6-3.8$ & $2.5-3.4$ \\
\hline BSI - Beach State Index ${ }^{b}$ & $0.7-0.8$ & $1.6-2.1$ & $0.9-1.0$ & $0.9-1.0$ \\
\hline BI - Beach Index ${ }^{c}$ & $2.1-2.2$ & $2.0-2.0$ & $2.1-2.2$ & $2.1-2.2$ \\
\hline BDI - Beach Deposit Index ${ }^{\mathrm{d}}$ & $62.4-71.1$ & $81.6-94.0$ & $88.3-102.7$ & $84.3-90.9$ \\
\hline
\end{tabular}

\footnotetext{
a Wright \& Short (1984), Short (1996)

b McLachlan and others (1993)

c McLachlan \& Dorvlo (2005)

d Soares (2003)
}

\section{Traffic Distribution}

Vehicle traffic was usually concentrated in the middle and upper sections of the beaches; these zones carried $91 \%$ of all beach traffic (Table 3). The distribution of beach traffic did vary to some extent seasonally and between beaches. For example, during the austral winter (August 2005), 79\% of vehicles on Teewah beach crossed the soft, upper shore, while $41 \%$ of all traffic in January 2006 occurred on the lower part of this beach (Table 3). Most drivers did, however, avoid driving on the lower shore and in the swash zone which accounted for only $9 \%$ of all recorded ORV traffic (Table 3). The concentration of traffic in the middle and upper sections of the beach resulted in up to 74 vehicle passes per hour in these areas, whereas traffic volumes on the lower shore were considerably lower at $0-10$ vehicles per hour.

\section{Macrobenthos Abundance and Diversity}

A total of 12,139 individuals were collected in the 720 samples, comprising 37 species. Polychaetes were the most speciose group with 15 species, followed by amphipods (6 species), bivalves (5 species) and isopods (4 species). One species each was recorded for gastropods and mysid shrimp. Crustaceans dominated the fauna numerically, comprising $72.8 \%$ of all individuals, followed by polychaetes $(23.3 \%)$, molluscs $(3.7 \%)$, and insects $(0.2 \%)$. Within the crustaceans, isopods and amphipods dominated the catches at $23.3 \%$ and $47.7 \%$ of total macrobenthos abundance respectively, whereas decapods $(0.14 \%)$ and mysids $(1.8 \%)$ were rarer.

A large number of samples from the ORV-impacted beaches contained no fauna, whereas invertebrates were found in almost all samples from the control beaches (Table 4). In fact, zero catches dominated the collections on the upper shore of beaches impacted by traffic where up to $97 \%$ of samples contained no fauna. On average, $84 \%$ of all sample units on the upper shore of impact beaches were void of animals, compared to only $12 \%$ on the reference beaches. In the middle section of the beach, $25-63 \%$ of samples from the impact beaches were found to be defaunated, whereas macrobenthos occurred in all but $2 \%$ of samples taken from reference sites (Table 4). These stark contrasts in faunal occurrence between impact and control sites were less pronounced on the lower shore and in the swash zone, but $7 \%$ of all cores from impact beaches were void of invertebrates compared with reference beaches that contained individuals in every single core taken (Table 4).

ORV-impacted beaches had significantly lower abundance, species richness, and diversity of macrobenthos (Figs. 5 and 6, Table 5). Contrasts did vary to some extent across a number of spatial and temporal scales (Table 5), 


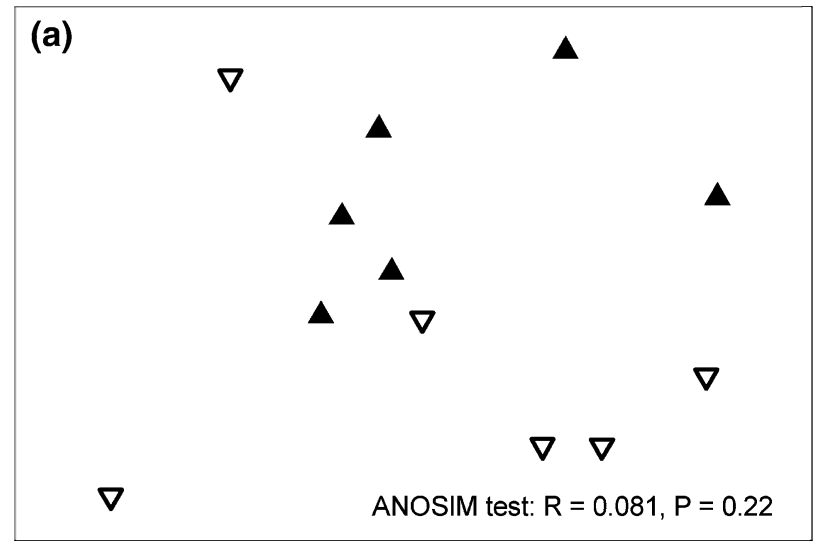

ORV-impacted beaches $\nabla$ Reference beaches

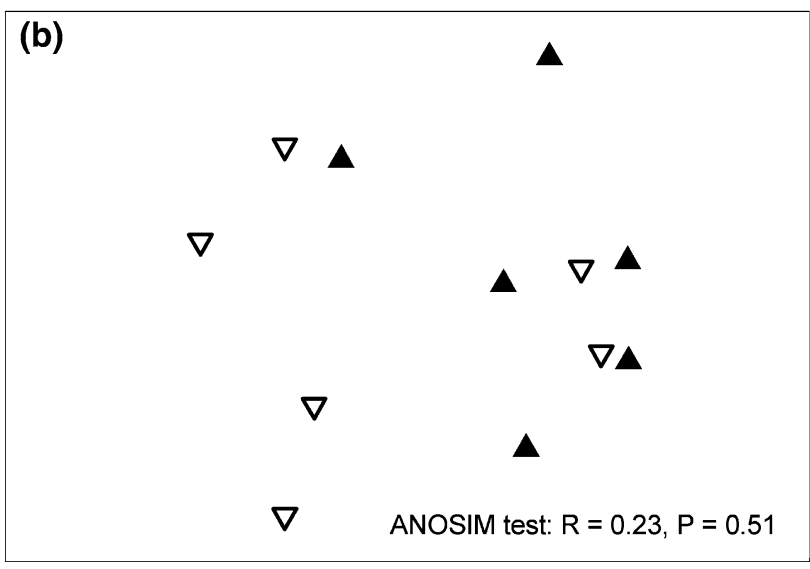

Fig. 2 Ordinations (nonmetric multidimensional scaling) comparing environmental conditions between beach sites subjected to ORV traffic and reference beaches. Top panel (a) is based on sediment properties (mean size, sorting, skewness, kurtosis, moisture), beach slope and beach width, and bottom panel (b) incorporates four composite indices of beach morphology (Omega, BDI, BI, BSI). Data are averaged over five transects per site and time. NMDS are based on normalized Euclidean distances

but overall there was a consistently strong effect of vehicle impact (i.e., reference versus ORV) on the upper and middle beach, irrespective of season (e.g., nonsignificant interaction term between impact $\times$ zone $\times$ time, Table 5).

On the lower shore and in the swash zone, mean total macrobenthos density was broadly comparable between reference $\left(163.6 \pm 16.5\right.$ Ind. $\left.\mathrm{m}^{-2}\right)$ and ORV-impacted beaches $\left(149.8 \pm 14.1\right.$ Ind. $\left.\mathrm{m}^{-2}\right)$. By contrast, the middle shore of impacted beaches supported only $34 \%$ of the total macrobenthos abundance recorded on reference beaches (ORV: $93.0 \pm 18.0$ Ind. $\mathrm{m}^{-2}$, Reference: $270.9 \pm 48.8$ Ind. $\mathrm{m}^{-2}$ ), and densities were reduced by two orders of magnitude on the upper shore (ORV: $3.8 \pm 1.3$ Ind. $\mathrm{m}^{-2}$, Reference: $458.4 \pm 114.4$ Ind. $\mathrm{m}^{-2}$ ). In the upper zone of reference beaches $1.41 \pm 0.09$ species were recorded on average per sample, but only $0.19 \pm 0.05$ species on the impact beaches, representing an $87 \%$ decline in species

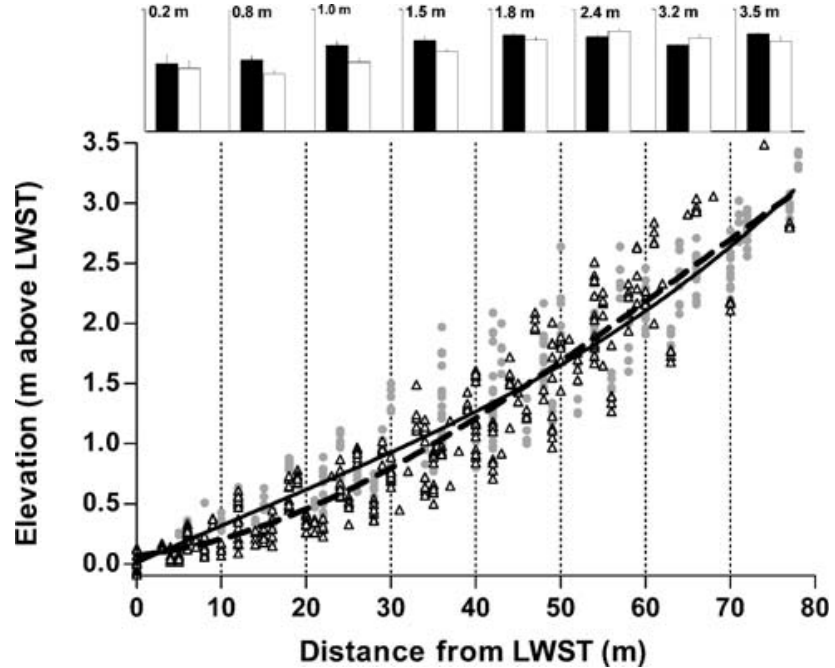

Fig. 3 Comparison of shore profiles between beaches subjected to ORV traffic (solid line and grey circles) and beaches without vehicle traffic (broken line and open triangles). Top panels contrast elevation between reference (open bars) and impact beaches (filled bars) in each of 10-m wide horizontal bands from the low water spring tide (LWST) mark to the base of the foredunes

Table 2 Hierachical ANOVA comparing mean sediment grain size across multiple spatial and temporal scales (data $\log _{10}+1$ transformed)

\begin{tabular}{lrllrr}
\hline Source term & df & SS & MS & F-Ratio & p \\
\hline A: ORV versus Controls & 1 & 0.15187 & 0.15187 & 1.99 & 0.2939 \\
B (A) Beach & 2 & 0.15271 & 0.07640 & 29.74 & $<0.0001$ \\
C: Zone & 2 & 1.07138 & 0.53569 & 47.15 & 0.0017 \\
A * C & 2 & 0.00726 & 0.00363 & 0.32 & 0.7435 \\
B * C (A) & 4 & 0.04500 & 0.01140 & 4.43 & 0.0017 \\
D: Time & 2 & 0.32806 & 0.16403 & 4.47 & 0.0955 \\
A * D & 2 & 0.09300 & 0.04650 & 1.27 & 0.3746 \\
B * D (A) & 4 & 0.14673 & 0.03670 & 14.29 & $<0.0001$ \\
C * D & 4 & 0.00296 & 0.07400 & 0.26 & 0.8927 \\
A * C * D & 4 & 0.02580 & 0.00645 & 2.30 & 0.1465 \\
B * C * D (A) & 8 & 0.02240 & 0.00280 & 1.09 & 0.3698 \\
Residual & 324 & 0.83173 & 0.00257 & & \\
Total (adjusted) & 359 & 2.87929 & & & \\
Total & 360 & & & & \\
\hline
\end{tabular}

density. The decrease in species density was equally substantial on the middle shore at $-61 \%$ (ORV: $1.07 \pm 0.13$ spp. sample ${ }^{-1}$, Reference: $2.78 \pm 0.13$ spp. sample ${ }^{-1}$ ). There was no marked difference in species density on the lower shore where few vehicles drive, with both reference $\left(3.58 \pm 0.12\right.$ spp. sample $\left.^{-1}\right)$ and impact beaches (3.34 \pm 0.17 spp. sample $\left.{ }^{-1}\right)$ recording similar species density (Fig. 5b). Similarly, values of Shannon-Wiener diversity indices were sharply reduced by a factor of 5 to 8 in samples from impact beaches on both the upper shore 


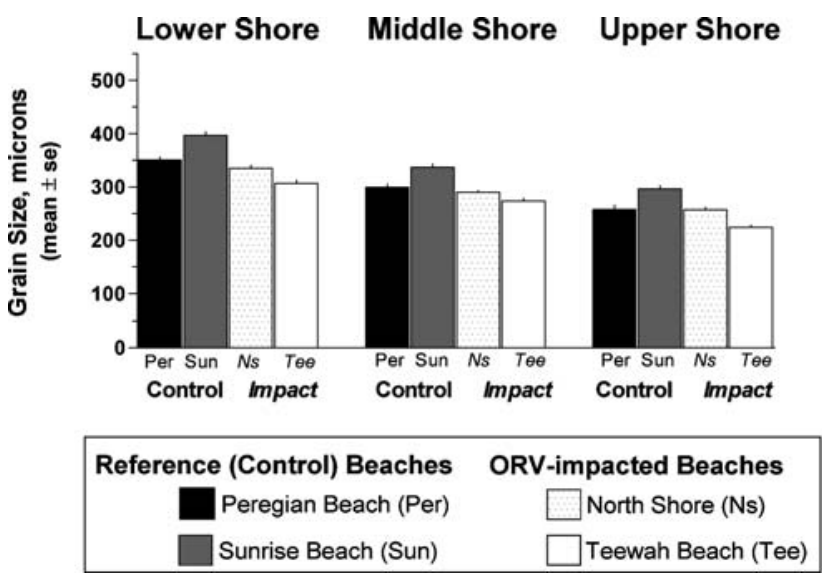

Fig. 4 Variation in sediment size (mean grain diameter) between beaches subjected to ORV traffic and beaches without vehicles in each of three zones across the beach face (c.f. Table 2 for inferential statistics)

(ORV: $0.02 \pm 0.013 \mathrm{H}^{\prime}$, Reference: $0.16 \pm 0.0 .03 \mathrm{H}^{\prime}$ ), and the middle shore (ORV: $0.14 \pm 0.026 \mathrm{H}$ ', Reference: $\left.0.69 \pm 0.044 \mathrm{H}^{\prime}\right)$.

\section{Shifts in Community Structure}

Community structure differed significantly between reference and ORV-impacted beaches (Figs. 7-9). These differences in community structure were generally small for the lower shore and swash zone, with considerable overlap between sites and low $r$-values (Fig. 8). By contrast, assemblages of the middle and upper shore on ORVimpact beaches, where most of the traffic is concentrated, are highly disjunct from those in the same zones on reference beaches (Fig. 8). These differences in community structure were detectable in all seasons, but generally became more pronounced during the austral summer when traffic volumes doubled (Fig. 8).

Neither any single nor a combination of environmental variables explained a sizeable fraction of the faunistic differences between impact and reference beaches (Table 6). By contrast, vehicle traffic was significantly correlated with changes in macrobenthos community structure, particularly on the upper and middle shore (Table 6). In these zones, the inclusion of sediment variables, or beach slope, did not measurably improve the correlations between biological and environmental similarity matrices over that explained by vehicle traffic alone. Because faunistic differences are not linked to variations in environmental conditions between treatments, vehicle traffic is likely to be the most parsimonious explanation for the observed difference in community structure between impact and reference beaches.

These shifts in assemblage structure on ORV-impacted beaches were on the upper shore driven mainly by sharp decreases in the abundance of the cirolanid isopod Pseudolana concinna (Table 7). This species occurred at a mean density of $435.09 \pm 114.4$ Ind. $\mathrm{m}^{-2}$ on beaches without vehicles, but only $0.97 \pm 0.41 \mathrm{Ind}^{-2} \mathrm{~m}^{-2}$ were on average found on impacted beaches. Other species of the upper shore that contributed to $>90 \%$ of total dissimilarity between impact and reference beaches were Insects, the amphipod Urohaustorius sp. 1 and the polychaete Glycera sp.1 (Table 7). Differences in community structure of the middle shore were spread over more species, with no single species driving the pattern as strongly as on the upper shore (Table 7). As was the case for the upper shore, Pseudolana concinna, Glycera sp.1, and Urohaustorius sp. 1 contributed most to overall dissimilarities, complemented by

Table 3 Distribution of vehicle traffic across the beach face (A), and traffic volumes (B) in each of three zones on the two beaches subjected to ORV traffic

\begin{tabular}{|c|c|c|c|c|c|}
\hline \multirow[t]{2}{*}{ Beach and zone } & \multicolumn{4}{|c|}{ (A) Proportion of Traffic } & \multirow{2}{*}{$\begin{array}{l}\text { (B) No. of Vehicles } \\
\text { per hour } \\
\text { min-max }\end{array}$} \\
\hline & Aug. '05 & Dec. '05 & Jan. '06 & All seasons & \\
\hline \multicolumn{6}{|l|}{ North Shore } \\
\hline Upper Shore & $23 \%$ & $6 \%$ & $17 \%$ & $16 \%$ & $4-15$ \\
\hline Middle Shore & $77 \%$ & $90 \%$ & $83 \%$ & $83 \%$ & $48-74$ \\
\hline Lower Shore \& Swash & $0 \%$ & $4 \%$ & $0 \%$ & $1 \%$ & $0-2$ \\
\hline \multicolumn{6}{|l|}{ Teewah } \\
\hline Upper Shore & $79 \%$ & $18 \%$ & $17 \%$ & $39 \%$ & $4-57$ \\
\hline Middle Shore & $21 \%$ & $70 \%$ & $42 \%$ & $44 \%$ & $10-25$ \\
\hline Lower Shore \& Swash & $0 \%$ & $12 \%$ & $41 \%$ & $17 \%$ & $0-10$ \\
\hline \multicolumn{6}{|c|}{ Both ORV-impacted Beaches } \\
\hline Upper Shore & $51 \%$ & $12 \%$ & $17 \%$ & $27 \%$ & $4-57$ \\
\hline Middle Shore & $49 \%$ & $80 \%$ & $63 \%$ & $64 \%$ & $10-74$ \\
\hline Lower Shore \& Swash & $0 \%$ & $8 \%$ & $20 \%$ & $9 \%$ & $0-10$ \\
\hline
\end{tabular}


Table 4 Comparison of the proportion of samples that contained no fauna ("null samples") between reference and impact beaches

\begin{tabular}{llrrr}
\hline Set & Zone & Reference beaches & ORV-impacted beaches & $\mathrm{P}_{(2)}$ \\
\hline Aug. 2005 & Upper Beach & $10 \%$ & $\mathbf{7 4 \%}$ & $<0.001$ \\
& Middle Beach & $5 \%$ & $\mathbf{2 5 \%}$ & 0.017 \\
& Lower Beach \& Swash & $0 \%$ & $0 \%$ & $<0$ \\
Dec. 2005 & Upper Beach & $19 \%$ & $\mathbf{9 6 \%}$ & $<0.001$ \\
& Middle Beach & $0 \%$ & $\mathbf{4 9 \%}$ & 0.002 \\
& Lower Beach \& Swash & $0 \%$ & $\mathbf{1 6 \%}$ & $<0.001$ \\
Jan. 2006 & Upper Beach & $8 \%$ & $\mathbf{8 7 \%}$ & $<0.001$ \\
& Middle Beach & $0 \%$ & $\mathbf{6 3 \%}$ & 0.142 \\
All Seasons & Lower Beach \& Swash & $0 \%$ & $3 \%$ & $<0.001$ \\
& Upper Beach & $12 \%$ & $\mathbf{8 4 \%}$ & $<0.001$ \\
& Middle Beach & $2 \%$ & $\mathbf{4 2 \%}$ & $\mathbf{7 \%}$ \\
\hline
\end{tabular}

Tabulated probability values $\left(\mathrm{P}_{(2)}\right)$ refer to two-sided tests of differences between proportions
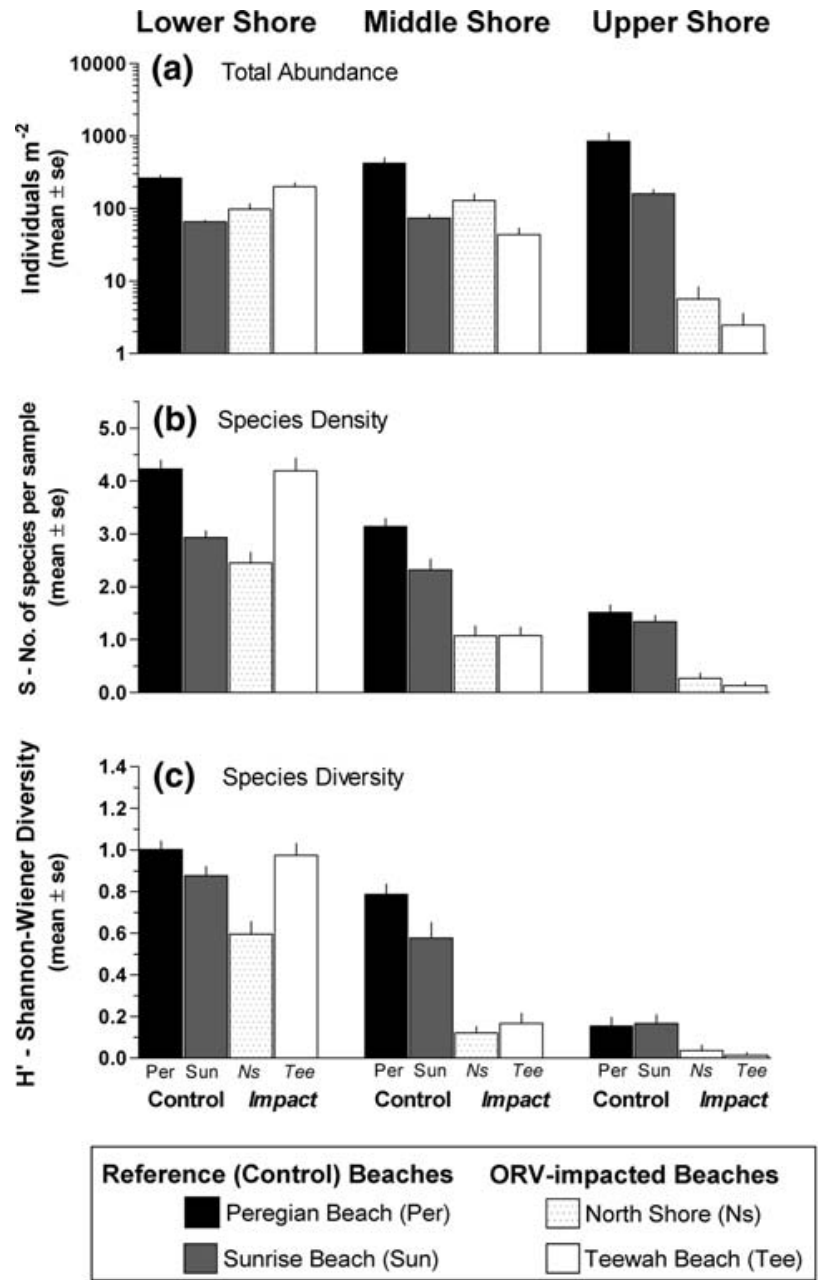

Fig. 5 Variation in (a) total macrobenthic abundance, (b) species density (No. of species per sample), and (c) species diversity (Shannon Wiener Index) between ORV-impacted beaches and reference beaches without vehicle traffic in each of three zones (c.f. Table 5 for inferential statistics) several other species of polychaetes, amphipods and two species of bivalves (Table 7).

Assemblage structure was more variable over time on ORV-impacted beaches (Table 8, Fig. 9), particularly on the upper and middle shore (Table 8, Fig. 9).

\section{Discussion}

Impacts of ORVs on Beach Macrobenthos

Macrobenthic assemblages on beaches subjected to vehicle traffic were composed of significantly fewer species at much reduced abundances, resulting in marked shifts in community structure compared with beaches closed to vehicles (Figs. 7 and 8). The most parsimonious explanation for the observed differences in macrobenthic communities between treatment and reference beaches is that vehicles reduce the fauna.

Ecological effect sizes were consistent with the distribution of traffic across the beach face: stronger differences were recorded on the upper and middle part of the beach where most $(91 \%)$ of the vehicle traffic occurred. Conversely, few vehicles generally drove on the lower beach or entered the swash zone, and macrobenthic assemblages in this zone had comparable density, species richness, and diversity between impact and reference sites (Fig. 5). This concordance of faunal differences and traffic distribution is consistent with the distribution of physical impacts caused by ORVs on sandy beaches in the region (Schlacher and Thompson 2007; Schlacher and Thompson in press). Vehicle traffic causes deep rutting of the soft, upper beach resulting in large volumes of sand being disturbed and displaced (Anders and Leatherman 1987). Similarly, most of the surface of the middle shore is covered by numerous, 
Table 5 Summary of hierarchical ANOVA comparing (A) total macrobenthos density (Ind. $\mathrm{m}^{-2}$ ), (B) species richness (No. of species per sample), and (C) species diversity (Shannon-Wiener Diversity Index) across multiple spatial and temporal scales

\begin{tabular}{|c|c|c|c|c|}
\hline Source term & df & $\begin{array}{l}\text { (A) Total density } \\
\left(\log _{10}(x+1) ; \text { Ind. } \mathrm{m}^{-2}\right) \\
\text { F-Ratio }\end{array}$ & $\begin{array}{l}\text { (B) Richness } \\
\text { (species sample }^{-1} \text { ) } \\
\text { F-Ratio }\end{array}$ & $\begin{array}{l}\text { (C) Diversity } \\
\text { (H' Shannon Index) } \\
\text { F-Ratio }\end{array}$ \\
\hline A: ORV versus controls (fixed) & 1 & 16.18 & 14.73 & 8.82 \\
\hline B (A) Beach (nested-random) & 2 & $12.49 * * *$ & $12.05 * * *$ & $7.66^{*}$ \\
\hline C: Zone (fixed) & 2 & $21.10 * *$ & $38.25 * *$ & $23.95 * *$ \\
\hline $\mathrm{A} * \mathrm{C}$ & 2 & 24.70** & $8.55 *$ & 3.24 \\
\hline $\mathrm{B} * \mathrm{C}(\mathrm{A})$ & 4 & 1.92 & $3.62 * *$ & $4.55^{* *}$ \\
\hline D: Time (fixed) & 2 & 1.19 & 1.01 & 0.85 \\
\hline $\mathrm{A} * \mathrm{D}$ & 2 & 0.39 & 1.89 & 4.79 \\
\hline $\mathrm{B} * \mathrm{D}(\mathrm{A})$ & 4 & $8.29 * *$ & $7.58 * * *$ & $2.60 *$ \\
\hline $\mathrm{C} * \mathrm{D}$ & 4 & 1.45 & 0.98 & 0.49 \\
\hline $\mathrm{A} * \mathrm{C} * \mathrm{D}$ & 4 & 2.12 & 2.06 & $3.99 *$ \\
\hline $\mathrm{B} * \mathrm{C} * \mathrm{D}(\mathrm{A})$ & 8 & 1.04 & 1.63 & 0.91 \\
\hline Residual & 324 & & & \\
\hline Total (adjusted) & 359 & & & \\
\hline Total & 360 & & & \\
\hline
\end{tabular}

overlapping tire tracks, whereas very few vehicles travel below the effluent line and in the swash (Schlacher and Thompson in press).

Community attributes of the macrobenthos on sandy beaches are strongly linked to physical conditions of the habitat (Defeo and McLachlan 2005). Assemblages on dissipative beaches with flat slopes, benign swash regimes, and fine sands comprise more species at higher densities than the less species and less abundant communities typical of steeper, reflective beaches that have harsher swash climates and coarser sands (McLachlan and others 1993; McLachlan and Dorvlo 2005). In the present situation, habitat attributes are highly unlikely to have driven the observed faunal differences between impact and reference beaches. Key habitat characteristics (e.g., sediment size, wave regimes, slope, etc.) of the ORV-impacted beaches did not markedly differ from reference sites, and all beaches had highly similar morphodynamic properties (Table 1, Figs. 2-4). Consequently, environmental variables were not significantly correlated with differences in community structure between impact and control beaches, but vehicle traffic was (Table 6).

Beach invertebrates can be killed at high intensities of vehicle traffic through direct crushing (Wolcott and Wolcott 1984; van der Merwe and van der Merwe 1991; Schlacher and others 2007a). The severity of these direct impacts appears to depend on the compactness of the sand, the sensitivity of individual species and the depth to which they are buried in the sand. For example, van der Merwe \& van der Merwe (1991) showed that (1) surf clams and whelks are less vulnerable to ORV impacts if buried in compact sand, (2) damage to intertidal species increases significantly if organisms are exposed on or near the surface of the sand, especially the soft-bodied mysid Gastrosaccus psammodytes, and (3) animals on the upper shore (in particular the isopod Tylos capensis) are highly susceptible to traffic impacts because of the softer sand and the tendency for ORV drivers to follow in the same tracks.

Spatial and Temporal Scales of Impacts

Disturbances differ mainly in the duration and intensity of impacts, and are commonly classified as pulse or press disturbance (Glasby and Underwood 1996; Lake 2000). Other important aspects of disturbances regimes include the types of impact forces, their frequency and predictability, and the spatial extent over which they operate (Lake 2000).

The effects of ORVs on sandy beaches are a combination of both the pulse and press type. Traffic volumes on the beaches studied are substantial in all seasons, with approximately 15,000 vehicles per month traversing the beach during the "low" season in the austral winter (press disturbance). Essentially, ORVs traverse the beaches on any given day of the year, except in unusually rough conditions during rare storm events. These base volumes rise sharply during the summer holidays to $>30,000$ vehicles per month, and several peak events occur during public holidays where traffic can exceed 5000 cars per day (pulse disturbance). Thus, disturbance forces applied by beach traffic are broadly predictable and consist of continuous press impacts amplified by several pulse events. The ecological impacts arising from such disturbance 

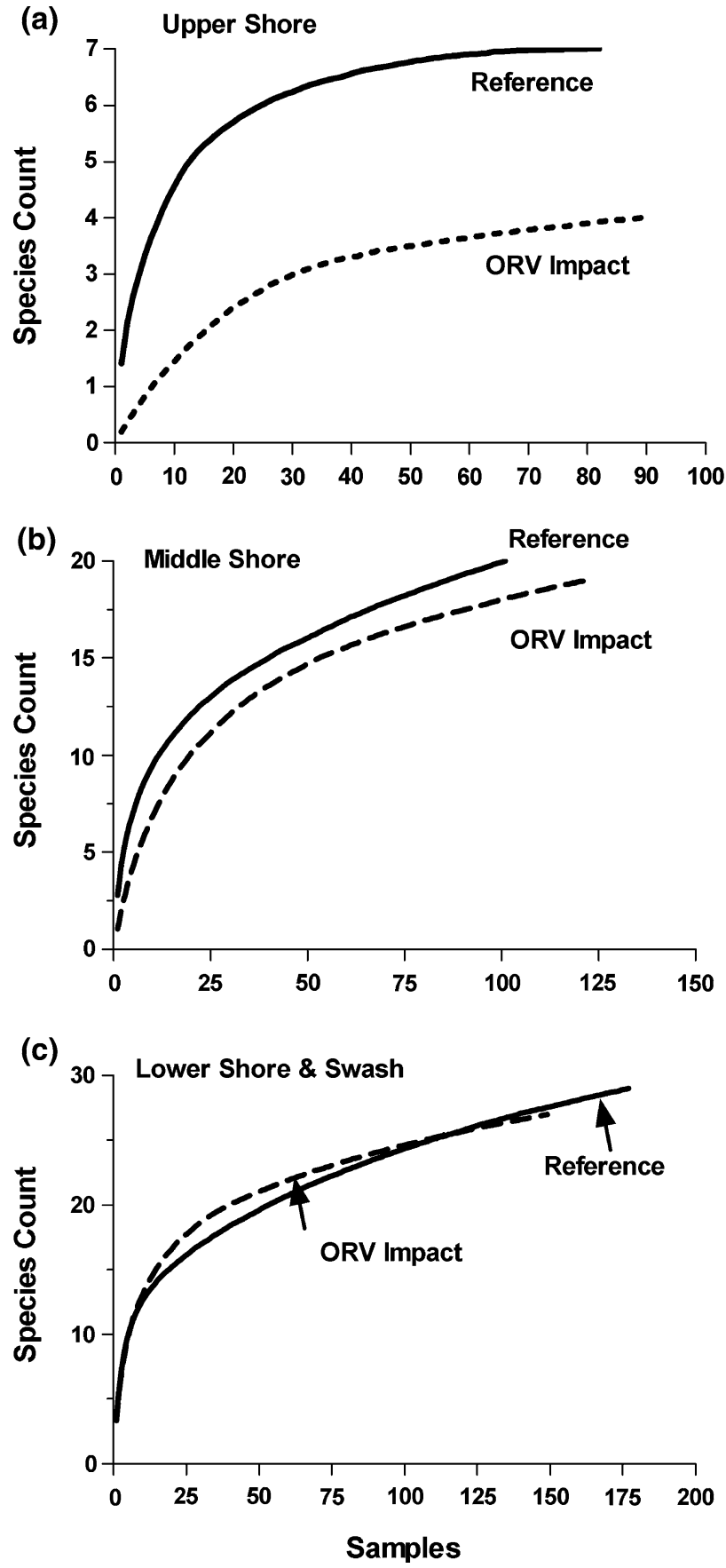

Fig. 6 Collector's curves comparing species accumulation rates between ORV-impacted beaches (broken lines) and reference beaches without vehicle traffic (solid lines) in each of three zones

regimes are thus likely to be continuous. Seasonal recovery of the fauna is therefore unlikely because a period of minimal impact does not exist in the present situation. In fact, differences in macrobenthic communities between ORV-impacted and reference beaches were clearly detectable during all seasons, the ecological effect size increasing during the peak traffic period in summer (Fig. 8).

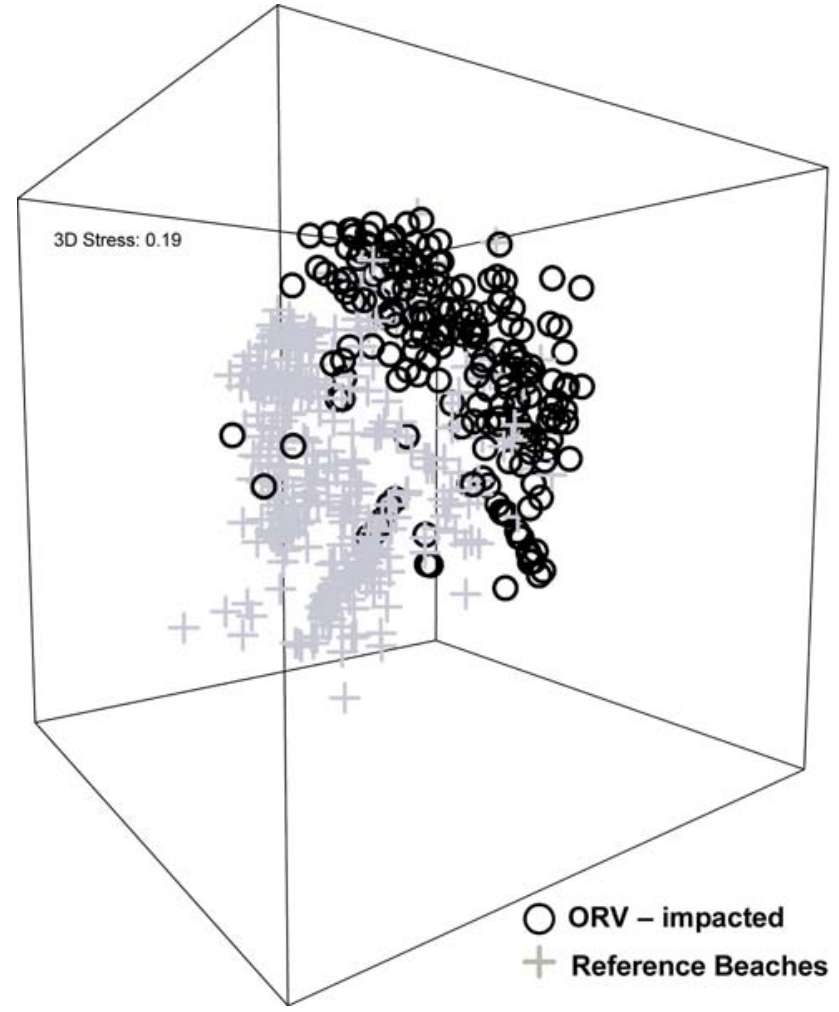

Fig. 7 Ordination (nonmetric dimensional scaling) contrasting community structure between ORV-impacted and reference beaches for all seasons and beach zones (ordination based on square-root transformed abundance data and Bray-Curtis resemblance coefficient)

The beaches studied by us are located in South-East Queensland which is Australia's fastest growing region with an annual population growth of $2.5 \%$ that occurs almost exclusively in the narrow coastal strip (Australian Bureau of Statistics 2004). Beaches are iconic assets in Australia, and it is the attractiveness of sandy beaches that underpins most of the coastal population growth (Jones and others in press). A distinct "beach lifestyle," linked strongly to hedonistic leisure activities, has developed over the last decades, and this culture is important in the economic development of the region (Legge Wilkinson 1996). Driving of ORVs on sandy beaches is a highly popular leisure activity, and long stretches of the region's beaches are open to ORV traffic. Beaches subjected to vehicle traffic include those on offshore barrier islands and in many National Parks and even in World-Heritage listed areas. Although the present study is the most comprehensive assessment of ORV impacts on invertebrate assemblages on sandy beaches, its spatial ambit was somewhat restricted at $<50 \mathrm{~km}$. The magnitude of the observed ecological effects caused by ORVs was large in the present situation; given the widespread use of ORVs on many beaches in the region at broadly similar traffic volumes, the spatial scale of these ecological impacts may be also be large. 
Fig. 8 Contrasts in community structure between ORVimpacted and reference beaches. Center panel depicts $r$-statistics from pairwise ANOSIM tests for each zone and season, illustrated by ordination (nonmetric multidimensional scaling) diagrams on periphery (solid symbols: ORV-impacted beaches, open symbols: reference beaches) (a) Aug. '05, Upper Shore

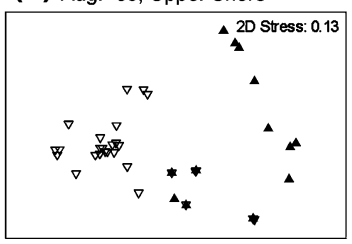

(b) Aug. '05, Mid Shore

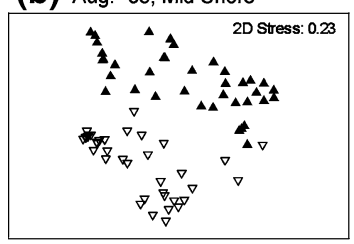

(d) Dec. '05, Mid Shore

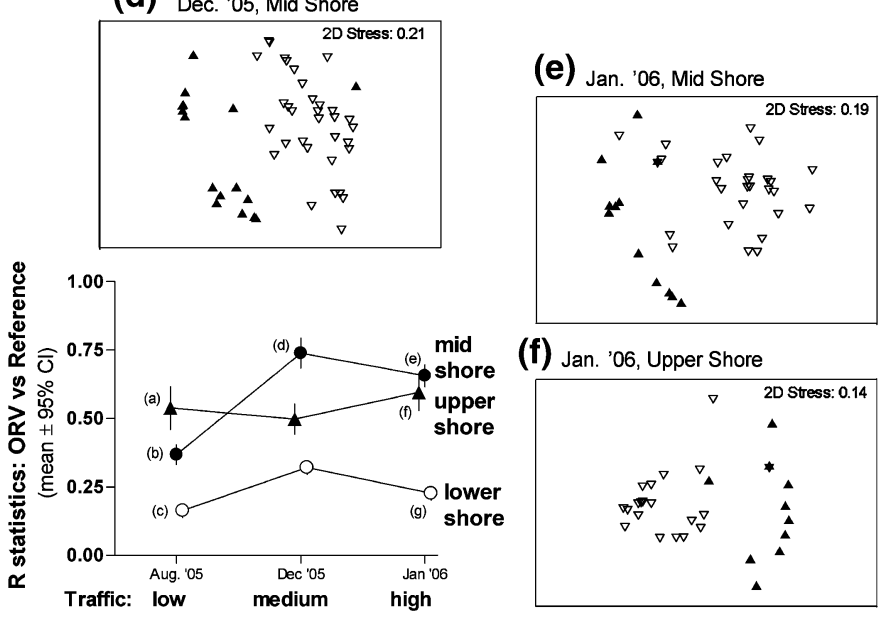

(c) Aug. '05, Lower Shore

(g) Jan. '06, Lower Shore
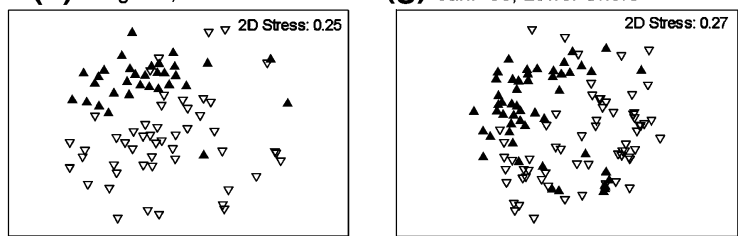
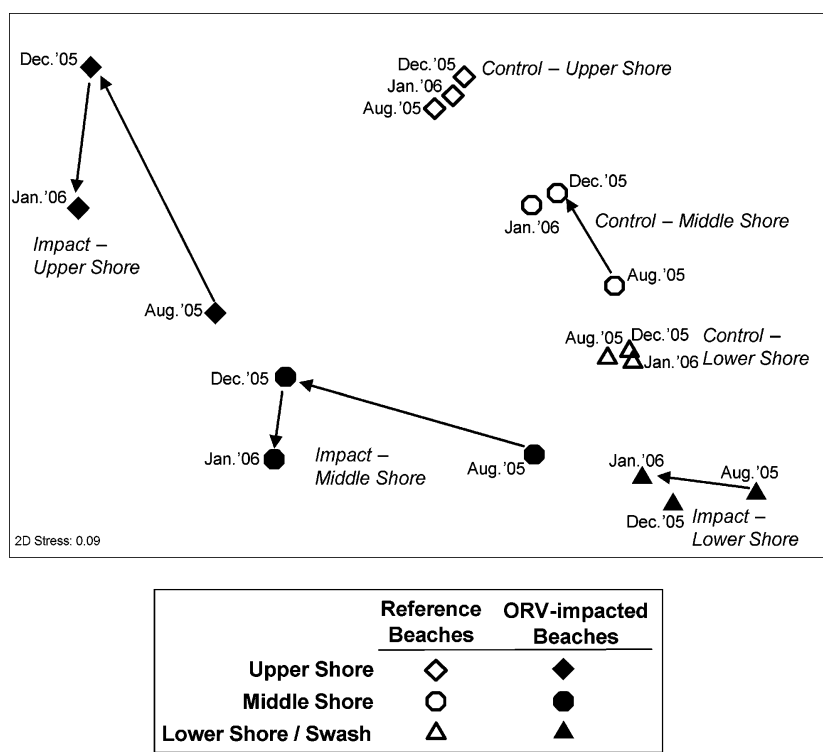

Fig. 9 Temporal variation in community structure for each zone (lower, middle, and upper shore) and treatment (impact versus control). Arrows show the magnitude and direction of community shifts

\section{Ecological Flow-On Effects}

Macrobenthic organisms are a key structural and functional component of sandy beach ecosystems. Benthic invertebrates play crucial roles in the cycling of nutrients (Cockroft and McLachlan 1993; Soares and others 1997), consume beach wrack deposited on the upper shore (Dugan and others 2003), and are important prey for fish, crabs, and shorebirds (Brown and McLachlan 1990; Du Preez and others 1990; Crawley and others 2006; McLachlan and Brown 2006; Peterson and others 2006). Substantial changes to these communities - as recorded in the present study caused by ORVs - may therefore have ramifications on ecosystem properties of sandy beaches beyond the impacts on the macrobenthos itself.

These ecological consequences are presently unknown and need to be assessed in order to formulate a comprehensive assessment of ORV effects on sandy beach ecosystems. Of particular interest to the public are putative effects on fishes and birds. It is possible that standing stocks of surf-zone fishes decline if food availability of their macrobenthic prey is reduced through the action of ORVs. Equally, shorebirds are highly sensitive to beach traffic (Williams and others 2004). Reported mechanisms causing population declines of shorebirds on beaches that are open to ORVs center mostly on direct kills (e.g., overruns and the destructions of nests) and disturbance to feeding (Buick and Paton 1989), but complementary mechanisms that operate via reduced food resources may also occur. Finally, ORVs are frequently forced high up onto the beach during high tides and rough seas and may travel in the dunes. Because dune vegetation is highly sensitive to physical disturbance by vehicles (Rickard and others 1994), invertebrates inhabiting dunes are vulnerable to crushing (Steiner and Leatherman 1981). Thus, the spatial ambit of the ecological impacts caused by ORV traffic extends beyond the unvegetated intertidal areas. In 
Table 6 Summary of BIOENV analysis matching similarities in environmental variables to corresponding similarities in faunal assemblages structure

\begin{tabular}{lllr}
\hline & $\begin{array}{l}\text { Upper shore } \\
\text { min-max }\end{array}$ & $\begin{array}{l}\text { Middle shore } \\
\text { min-max }\end{array}$ & $\begin{array}{c}\text { Lower shore } \\
\text { min-max }\end{array}$ \\
\hline Sediment & & & $0.018-0.040$ \\
$\quad$ Mean grain size & $0.061-0.086$ & $0.052-0.122$ & $0.024-0.036$ \\
$\quad$ Skewness & $0.038-0.057$ & $0.005-0.022$ & $-0.016-0.034$ \\
$\quad$ Sorting & $0.008-0.027$ & $0.080-0.115$ & $0.001-0.021$ \\
$\quad$ Kurtosis & $0.013-0.031$ & $0.017-0.079$ & $0.045-0.105 * *$ \\
$\quad$ Moisture & $0.023-0.060$ & $-0.003-0.053$ & $0.096-0.147 * * * * *$ \\
Beach slope & $-0.033-0.024$ & $0.069-0.164 * *$ & $0.185-0.199 * * * * *$ \\
Vehicle traffic & $0.463-0.529 * * * * *$ & $0.402-0.456 * * * * *$ & $0.207-0.243$ \\
Best combination & $0.463-0.529$ & $0.424-0.456$ & 0.06 \\
\hline
\end{tabular}

Tabulated values are Spearman correlation coefficients for both single environmental variables and the sub-set of variables having the best match. Analyses were run for both raw faunal abundance data and four data transformations $\left(\mathrm{x}=\mathrm{x}^{0.5}, \mathrm{x}=\mathrm{x}^{0.25}, \mathrm{x}^{\prime}=\log _{10}(\mathrm{x}+1), \mathrm{x}^{\prime}=\operatorname{pres}^{\prime}\right.$ abs); tabulated values are the range of coefficients, and asterisks denote how often a variable was included in the best sub-set

the present situation, vehicle tracks were observed on the foredunes and these tracks contained crushed ghost crabs (Schlacher personal observation).

\section{Management Implications}

Beaches are prime sites for human recreation (de Ruyck and others 1997; Davenport and Davenport 2006). Leisure activities span a broad spectrum of uses ranging from lowimpact activities, such as bird-watching and walking, to high-impact pursuits, such as ORV driving. Although ORV driving on beaches is highly popular and widespread in Australia and elsewhere, all beach users do not necessarily perceive it is as an acceptable form of outdoor recreation; in fact, coastal tourists perceive driving of vehicles on beaches to be highly harmful to the environment (Priskin 2003a). ORVs also greatly diminish the wilderness character of beaches and reduce their attractiveness for people to engage in "nature experiences" (Wilkinson 2001). From an ecological perspective, the impacts of ORVs can be wide-ranging and severe (Palmer and Leatherman 1979; Godfrey and Godfrey 1980) and this study provides clear evidence on the impacts by ORVs on beach invertebrates.

Ecological impacts caused by beach traffic provide arguments to restrict the use of ORVs on beaches, but social and economic demands may favor the opening of beaches to vehicles (Celliers and others 2004). Local and regional economies can, arguably, benefit from ORV traffic on beaches (Silberman and Andereck 2006), and some beaches may only be accessible by ORVs (Celliers and others 2004). Conversely, nonORV users are likely to be deterred from visiting beaches with excessive vehicle traffic, removing a potential income source for local businesses. In the present situation, the beaches north of Noosa are immensely popular for fishing and beach camping, and serve as a transit route for beaches further to the north. Quantitative data on the social acceptance of beach traffic and its economic costs and benefits generally do not exist for most beaches, and the management of beach traffic is therefore not based on defensible data or inclusive of social, economic, and ecological dimensions (Schlacher and others 2006; Schlacher and others 2007a, 2007b).

Key requirements of beach management plans are to minimize conflicts between different user groups while conserving the ecological features of beaches (James 2000; Celliers and others 2004). From an environmental conservation perspective it is thus prudent to restrict traffic volumes on beaches where ecological effects are demonstrably caused by vehicles (this study). Setting limits on traffic volumes does, however, require information on the relationship between traffic intensity and impact sizes in order to determine threshold levels of traffic above which ecologically significant impacts do occur. These data are currently only available for ghost crabs in a single locality (Schlacher and others 2007a), and more field experiments are therefore required to identify impact thresholds for a range of communities and beach types. Overall, multiple issues caused by ORV traffic on sandy beaches are increasingly confronting coastal managers. Management strategies and actions need to be broadly accommodating of social, cultural, and economic demands and include conservation measures based on defensible and robust data on the ecological responses of beaches to human pressures.

Acknowledgments We greatly appreciate the assistance of our postgraduate students who valiantly battled climatic extremes and 
Table 7 Summary of SIMPER analysis identifying the contribution of individual species to total dissimilarity between macrobenthic assemblages on ORV-impacted beaches and beaches without vehicle traffic

\begin{tabular}{|c|c|c|c|c|c|c|c|}
\hline $\begin{array}{l}\text { Upper shore } \\
\text { Species }\end{array}$ & Taxon $^{\mathrm{a}}$ & $\begin{array}{l}\text { Impact: } \\
\text { Mean density } \\
\text { (Ind. } \mathrm{m}^{-2} \text { ) }\end{array}$ & $\begin{array}{l}\text { Control: } \\
\text { Mean density } \\
\left(\text { Ind. } \mathrm{m}^{-2} \text { ) }\right.\end{array}$ & Av. Diss & Diss./SD & Contrib. \% & Cum.\% \\
\hline Pseudolana concinna & Iso & 0.97 & 435.09 & 67.45 & 2.12 & 70.27 & 70.27 \\
\hline Insecta spp. & Ins & 0.71 & 1.71 & 9.82 & 0.44 & 10.23 & 80.51 \\
\hline Urohaustorius sp.1 & Amp & 0.00 & 3.40 & 6.10 & 0.38 & 6.35 & 86.86 \\
\hline Glycera sp.1 & Pol & 0.00 & 3.50 & 5.85 & 0.43 & 6.09 & 92.95 \\
\hline $\begin{array}{l}\text { Middle shore } \\
\text { Species }\end{array}$ & & $\begin{array}{l}\text { Impact } \\
\text { Mean density } \\
\left(\text { Ind. } \mathrm{m}^{-2} \text { ) }\right.\end{array}$ & $\begin{array}{l}\text { Control } \\
\text { Mean density } \\
\text { (Ind. } \mathrm{m}^{-2} \text { ) }\end{array}$ & Av. Diss & Diss./SD & Contrib.\% & Cum.\% \\
\hline Pseudolana concinna & Iso & 4.08 & 110.34 & 20.61 & 1.04 & 21.48 & 21.48 \\
\hline Glycera sp.1 & Pol & 0.09 & 19.51 & 18.56 & 0.80 & 19.34 & 40.82 \\
\hline Urohaustorius sp.1 & Amp & 0.09 & 38.80 & 14.35 & 0.88 & 14.95 & 55.78 \\
\hline Ophelia sp.1 & Pol & 18.65 & 77.66 & 10.01 & 0.63 & 10.43 & 66.21 \\
\hline Donax deltoides & Biv & 0.64 & 4.65 & 6.49 & 0.44 & 6.76 & 72.97 \\
\hline Paphies elongata & Biv & 2.87 & 2.31 & 5.95 & 0.47 & 6.20 & 79.17 \\
\hline Exoediceros sp.1 & Amp & 51.34 & 4.09 & 5.57 & 0.50 & 5.80 & 84.97 \\
\hline Urothoe sp.1 & Amp & 0.00 & 4.93 & 2.34 & 0.33 & 2.44 & 87.41 \\
\hline Polydora sp. & Pol & 0.54 & 5.35 & 2.26 & 0.34 & 2.36 & 89.77 \\
\hline Australonuphis sp.1 & Pol & 2.14 & 0.00 & 2.04 & 0.32 & 2.13 & 91.90 \\
\hline $\begin{array}{l}\text { Lower shore and swash } \\
\text { Species }\end{array}$ & & $\begin{array}{l}\text { Impact } \\
\text { Mean density } \\
\left(\text { Ind. } \mathrm{m}^{-2} \text { ) }\right.\end{array}$ & $\begin{array}{l}\text { Control } \\
\text { Mean density } \\
\left(\text { Ind. } \mathrm{m}^{-2} \text { ) }\right.\end{array}$ & Av. Diss & Diss./SD & Contrib. \% & Cum.\% \\
\hline Polydora sp.1 & Pol & 13.21 & 44.24 & 9.39 & 0.97 & 11.23 & 11.23 \\
\hline Pseudolana elegans & Iso & 68.67 & 6.80 & 9.36 & 0.97 & 11.19 & 22.42 \\
\hline Glycera sp.1 & Pol & 0.00 & 12.71 & 8.23 & 0.69 & 9.84 & 32.26 \\
\hline Exoediceros sp.1 & Amp & 27.61 & 11.69 & 8.15 & 0.87 & 9.75 & 42.01 \\
\hline Urohaustorius sp.1 & Amp & 2.56 & 52.55 & 7.13 & 0.77 & 8.53 & 50.54 \\
\hline Paphies elongata & Biv & 4.84 & 6.29 & 5.99 & 0.65 & 7.16 & 57.70 \\
\hline Gastrosaccus sp.1 & Mys & 7.85 & 5.03 & 5.62 & 0.78 & 6.72 & 64.42 \\
\hline Nephtys longipes & Pol & 11.25 & 0.18 & 5.51 & 0.73 & 6.59 & 71.01 \\
\hline Donax deltoides & Biv & 1.01 & 5.81 & 5.31 & 0.61 & 6.35 & 77.36 \\
\hline Tittakunara katoa & Amp & 2.49 & 6.77 & 5.21 & 0.61 & 6.23 & 83.59 \\
\hline Pseudolana concinna & Iso & 0.00 & 4.33 & 1.83 & 0.32 & 2.19 & 85.78 \\
\hline Urothoe sp.1 & Amp & 1.16 & 3.60 & 1.76 & 0.35 & 2.10 & 87.89 \\
\hline Donax brazeri & Biv & 0.87 & 1.20 & 1.64 & 0.39 & 1.96 & 89.84 \\
\hline Australonuphis sp.1 & Pol & 1.66 & 0.30 & 1.58 & 0.36 & 1.89 & 91.73 \\
\hline
\end{tabular}

${ }^{a}$ Codes for higher taxa: Iso - Isopoda, Amp - Amphipoda, Pol - Polychaeta, Biv - Bivalvia, Mys - Mysidacea

Table 8 Relative dispersion values for temporal changes in macrobenthic communities within each zone for impact and control beaches

\begin{tabular}{lllll}
\hline & & Upper shore & Middle shore & Lower shore and swash \\
\hline ORV-impacted beaches & Noosa North Shore & 1.436 & 1.538 & 1.308 \\
& Teewah Beach & 1.179 & 1.358 & 1.615 \\
Reference beaches & Sunrise Beach & 0.769 & 0.564 & 0.462 \\
& Peregian Beach & 0.615 & 0.513 & 0.615 \\
\hline
\end{tabular}


manually processed truckloads (literally) of sand. "Thank You" to Luke Thompson, Sam Price, Sophie Leonardi, Anna Patricio, Marina D'Andrade, Rohan Wilson, Tara Nielsen, Serena Lucrezi, and Stewart Lloyd. The local government authority charged with managing the beaches, Noosa Shire Council, provided funds for this study, and its pro-active approach to base coastal management on scientifically robust assessments of impacts was instrumental in conducting the work.

\section{References}

Anders FJ, Leatherman SP (1987) Disturbance of beach sediment by off-road vehicles. Env Geol Water Sci 9:183-189

Australian Bureau of Statistics (2004) How many people live in Australia's coastal areas? Year Book Australia, 2004. Australian Bureau of Statistics, Canberra

Bascom W (1980) Waves and beaches: the dynamics of the ocean surface. Anchor Press, Garden City, New York

Blankensteyn A (2006) O uso do caranguejo maria-farinha Ocypode quadrata (Fabricius) (Crustacea, Ocypodidae) como indicador de impactos antropogênicos em praias arenosas da Ilha de Santa Catarina, Santa Catarina, Brasil. Rev Bras Zool 23:870-876

Blott SJ, Pye K (2001) GRADISTAT: A grain size distribution and statistics package for the analysis of unconsolidated sediments. Earth Surf Process Landf 26:1237-1248

Brown AC, McLachlan A (1990) Ecology of sandy shores. Elsevier, Amsterdam

Brown AC, McLachlan A (2002) Sandy shore ecosystems and the threats facing them: some predictions for the year 2025. Environ Conserv 29:62-77

Buckley R (ed) (2004) Environmental impacts of ecotourism. CABI Pub., Cambridge, MA, USA

Buick AM, Paton DC (1989) Impact of off-road vehicles on the nesting success of Hooded Plovers Charadrius rubricollis in the Coorong region of South Australia. EMU 89:159-172

Celliers L, Moffett T, James NC, Mann BQ (2004) A strategic assessment of recreational use areas for off-road vehicles in the coastal zone of KwaZulu-Natal, South Africa. Ocean Coast Manage 47:123-140

Clarke KR (1993) Non-parametric multivariate analyses of changes in community structure. Aus J Ecol 18:117-143

Clarke KR, Ainsworth M (1993) A method of linking multivariate community structure to environmental variables. Mar Ecol Prog Ser 92:205-219

Clarke KR (1999) Nonmetric multivariate analysis in communitylevel ecotoxicology. Environ Toxicol Chem 18:118-127

Clarke KR, Warwick RM (2001) Change in marine communities: an approach to statistical analysis and interpretation. PRIMER-E, Plymouth

Cockroft AC, McLachlan A (1993) Nitrogen budget for a high energy ecosystem. Mar Ecol Prog Ser 100:287-299

Crawley KR, Hyndes GA, Ayvazian SG (2006) Influence of different volumes and types of detached macrophytes on fish community structure in surf zones of sandy beaches. Mar Ecol Prog Ser 307:233-246

Davenport J, Davenport JL (2006) The impact of tourism and personal leisure transport on coastal environments: a review. Est Coast Shelf Sci 67:280-292

de Ruyck A, Soares AG, McLachlan A (1997) Social carrying capacity as a management tool for sandy beaches. J Coast Res $13: 822-830$

Defeo O, McLachlan A (2005) Patterns, processes and regulatory mechanisms in sandy beach macrofauna: a multi-scale analysis. Mar Ecol Prog Ser 295:1-20
Du Preez HH, McLachlan A, Marais JFK, Cockroft AC (1990) Bioenergetics of fishes in a high-energy surf zone. Mar Biol 106:1-12

Dugan JE, Hubbard DM, McCrary MD, Pierson MO (2003) The response of macrofauna communities and shorebirds to macrophyte wrack subsidies on exposed sandy beaches of southern California. Est Coast Shelf Sci 58:25-40

Glasby TM, Underwood AJ (1996) Sampling to differentiate between pulse and press perturbations. Environ Monit Assess 42:241-252

Godfrey PJ, Godfrey M (1980) Ecological effects of off-road vehicles on Cape Cod. Oceanus 23:56-67

Gormsen E (1997) The impact of tourism on coastal areas. GeoJournal 42:39-54

Heymans JJ, McLachlan A (1996) Carbon budget and network analysis of a high-energy beach/surf-zone ecosystem. Est Coast Shelf Sci 43:485-505

Hosier PE, Kochhar M, Thayer V (1981) Off-road vehicle and pedestrian track effects on the sea-approach of hatchling loggerhead turtles. Environ Conserv 8:158-161

James RJ (2000) From beaches to beach environments: linking the ecology, human-use and management of beaches in Australia. Ocean Coast Manage 43:495-514

Jones AR, Gladstone W, Hacking NJ Australian sandy-beach ecosystems and climate change: ecology and management. Aust Zool in press (in press)

Klein YL, Osleeb JP, Viola MR (2004) Tourism-generated earnings in the coastal zone: a regional analysis. J Coast Res 20:10801088

Lake PS (2000) Disturbance, patchiness, and diversity in streams. J N Am Benthol Soc 19:573-592

Legge Wilkinson M (1996) Human impacts on sandy beaches - results from the SOS95 beach survey, Surfrider Foundation Australia, Dee Why, New South Wales, Australia

Luckenbach RA, Bury BR (1983) Effects of off-road vehicles on the biota of the Algodones Dunes, Imperial County, California. J Appl Ecol 20:265-286

McLachlan A, Jaramillo E, Donn Jr TE, Wessels F (1993) Sandy beach macrofauna communities and their control by the physical environment: a geographical comparison. J Coast Res 15:27-38

McLachlan A, Dorvlo A (2005) Global patterns in sandy beach macrobenthic communities. J Coast Res 21:674-687

McLachlan A, Brown AC (2006) The ecology of sandy shores. Academic Press, Burlington, MA, USA

Micallef A, Williams AT (2002) Theoretical strategy considerations for beach management. Ocean Coast Manage 45:261-275

Moss D, McPhee DP (2006) The impacts of recreational four-wheel driving on the abundance of the Ghost Crab (Ocypode cordimanus) on subtropical beaches in SE Queensland. Coast Manage 34:133-140

Nordstrom KF (2000) Beaches and dunes on developed coasts. Cambridge University Press, Cambridge, UK

Palmer JF, Leatherman SP (1979) Off-road vehicle usage on federally managed coastal parklands, UM/NPSCRU Report No. 46

Peterson CH, Bishop MJ, Johnson GA, D'Anna LM, Manning LM (2006) Exploiting beach filling as an unaffordable experiment: benthic intertidal impacts propagating upwards to shorebirds. J Exp Mar Biol Ecol 338:205-221

Priskin J (2003a) Tourist perceptions of degradation caused by coastal nature-based recreation. Environ Manage 32:189-204

Priskin J (2003b) Physical impacts of four-wheel drive related tourism and recreation in a semi-arid, natural environment. Ocean Coast Manage 46:127-155

Richardson D, Schlacher TA, Pietsch C, Thompson LMC, McLean I, Smith R (2006) Noosa North Shore: Ecological impacts of vehicular traffic (Final report prepared for Noosa Shire Council). WBM Oceanics, Brisbane, Australia 
Rickard CA, McLachlan A, Kerley GIH (1994) The effects of vehicular and pedestrian traffic on dune vegetation in South Africa. Ocean Coast Manage 23:225-247

Schlacher TA, Schoeman DS, Lastra M, Jones A, Dugan J, Scapini F, McLachlan A (2006) Neglected ecosystems bear the brunt of change. Ethol Ecol Evol 18:349-351

Schlacher TA, Thompson LMC (2007) Exposure of fauna to off-road vehicle (ORV) traffic on sandy beaches. Coast Manage 35: 567-583

Schlacher TA, Thompson LMC, Price S (2007a) Vehicles versus conservation of invertebrates on sandy beaches: quantifying direct mortalities inflicted by off-road vehicles (ORVs) on ghost crabs. Mar Ecol - Evol Persp 28:354-367

Schlacher TA, Dugan J, Schoeman DS, Lastra M, Jones A, Scapini F, McLachlan A, Defeo O (2007b) Sandy beaches at the brink. Divers Distrib 13:556-560

Schlacher TA, Thompson LMC Physical impacts caused by off-road vehicles (ORVs) to sandy beaches: spatial quantification of car tracks on an Australian barrier island. J Coast Res in press (in press)

Short AD (1996) The role of wave height, period, slope, tide range and embaymentisation in beach classifications - a review. Rev Chil Hist Nat 69:589-604

Silberman J, Andereck KL (2006) Economic value of off-highway vehicle recreation. J Leis Res 38:208-223

Soares AG, Schlacher TA, McLachlan A (1997) Carbon and nitrogen exchange between sandy beach clams (Donax serra) and kelp beds in the Benguela Coastal Upwelling Region. Mar Biol 127:657-664

Soares AG (2003) Sandy beach morphodynamics and macrobenthic communities in temperate, subtropical and tropical regions: a macroecological approach. Ph.D thesis, University of Port Elizabeth
Steiner AJ, Leatherman SP (1981) Recreational impacts on the distribution of Ghost Crabs (Ocypode quadrata). Biol Conserv 20:111-122

Stephenson G (1999) Vehicle impacts on the biota of sandy beaches and coastal dunes - a review from a New Zealand perspective, Department of Conservation, Wellington, New Zealand

Underwood AJ (1981) Techniques of analysis of variance in experimental marine biology and ecology. Oceanogr Mar Biol Annu Rev 19:513-605

Underwood AJ (1997) Experiments in ecology: their logical design and interpretation using analysis of variance. Cambridge University Press, Cambridge, U.K

van der Merwe D, van der Merwe D (1991) Effects of off-road vehicles on the macrofauna of a sandy beach. S Afr J Sci 87:210-213

Warwick RM, Clarke KR (1993) Increased variability as a symptom of stress in marine communities. J Exp Mar Biol Ecol 172:215226

Watson JJ, Kerley GIH, McLachlan A (1996) Human activity and potential impacts on dune breeding birds in the Alexandria Coastal Dunefield. Landscape Urban Plan 34:315-322

Wilkinson T (2001) On the beaten path. National Parks Conservation Association March-April online: http://www.npca.org/magazine/ 2001/march_april

Williams JA, Ward VL, Underhill LG (2004) Waders respond quickly and positively to the banning of off-road vehicles from beaches in South Africa. Wader Study Group Bull 104:79-81

Wolcott TG, Wolcott DL (1984) Impact of off-road vehicles on macroinvertebrates of a Mid-Atlantic beach. Biol Conserv 29:217-240

Wright LD, Short AD (1984) Morphodynamics variability of surf zones and beaches: A synthesis. Mar Geol 56:93-118 